\title{
Reading and Writing Strategies Used by Typical and Struggling Readers: A Cross-Sectional Survey
}

\author{
Sotiria Tzivinikou, Dimitra Kagkara, Alexandra Fountoukidou, Eirini Kakoura \\ Department of Special Education, University of Thessaly, Volos, Greece \\ Email: sotitzivi@uth.gr
}

How to cite this paper: Tzivinikou, S., Kagkara, D., Fountoukidou, A., \& Kakoura, E. (2021). Reading and Writing Strategies Used by Typical and Struggling Readers: A Cross-Sectional Survey. Psychology, 12, 692706.

https://doi.org/10.4236/psych.2021.125043

Received: March 7, 2021

Accepted: May 21, 2021

Published: May 24, 2021

Copyright $\odot 2021$ by author(s) and Scientific Research Publishing Inc. This work is licensed under the Creative Commons Attribution International License (CC BY 4.0).

http://creativecommons.org/licenses/by/4.0/

(c) (i) Open Access

\begin{abstract}
Reading and writing are essential skills to master for university students, as research has shown that effective use of reading and writing strategies can lead to academic success. There are contradictory studies regarding whether reading and writing strategies differ between typical and struggling higher education students. The present study aims to compare the quantities variations of learning strategies and the qualities variations to the strategy between typical and struggling students in Greek higher education. It is a cross-sectional survey. The sampling was convenient, consisted of 233 undergraduate Greek students; 46 were self-reported as struggling readers. The research instruments employed in the present study were two scales for reading and writing strategies usage, based on Oxford (1990) classification system. The results suggest that typical students tend to considerably use reading and writing strategies more often than struggling students. Although these students use fewer reading and writing strategies, they tend to use cognitive and metacognitive strategies.
\end{abstract}

\section{Keywords}

Reading Strategies, Writing Strategies, Typical and Struggling Readers

\section{Introduction}

The term learning strategies have been employed in the literature several decades earlier to describe "plans, routines, or activities" used regularly and purposefully or "a collection of mental tactics employed by an individual in a particular learning situation" (Brown et al., 1983: p. 100). Similarly, other researchers consider learning strategies as the means of selecting, combining and rede- 
signing cognitive routines or as behaviours of a learner that are intended (Kirby, 1988; Mayer, 1988). On the other hand, Oxford (1990) uses Rigney's (1978) definition of learning strategies as "operations employed by the learner to aid the acquisition, storage, retrieval, and use of information" (p. 8). It classifies learning strategies into six distinct categories: memory, cognitive, metacognitive, compensation, affective and social. Nevertheless, all researchers agree that learning strategies are used consciously to reinforce and assist the learning process and promote the acquisition, retention, and retrieval of knowledge.

\section{Theoretical Background}

\section{Learning Strategy Used by Successful and Struggling Readers and Writers}

Learning strategies are vital for improving students' critical thinking skills and self-efficacy (Antoniou, Geralexis, \& Charitaki, 2017). Also, they bridge the gap between strong and weak areas, promote independent learning, raise students' awareness of how they learn, and aid the students in comprehending the process of learning (Meltzer et al., 2006).

In the same vein, the results of several studies confirm that proficient readers and writers use a wide range of reading and writing strategies (Anderson, 2003; Block, 1992; Nisbet \& Shucksmith, 2017; Mitchell \& Sutherland, 2020; Mokhtari \& Reichard, 2004; Mokhtari \& Sheorey, 2002; Oxford, 1990; Oxford, 2016; Tzivinikou \& Fountoukidou, 2017).

Several decades earlier, Pressley and Afflerbach (1995) pointed out that successful readers read strategically and have a specific purpose when they read. They have sufficient metacognitive awareness to develop, select, and apply learning strategies. Cunningham and Stanovich (1998) support the view that good readers can read the words accurately and fluently, enabling them to understand a text. They also often think about or reflect on what they read, make inferences, and rephrase a passage in their own words as well as have the skill to use their prior knowledge to make predictions about what may happen next and understand ideas that may come across (Palincsar \& Brown, 1984; Paris et al., 1983).

Similarly, good writers have adequate knowledge on their topics and, as a result, easily access relevant ideas during writing (Graham \& Harris, 1992; Graham \& Perry, 1993; Kellogg, 1987). Thus, the most appropriate learning process involves helping the learner engage with the topic to develop understanding and connect the latest information to their background knowledge. It can be achieved if the learner asks the most relevant questions to evolve into comprehension. Many learners, e.g., students with dyslexia, struggle to ask the right questions. They may depend on the hints and reminders given by the teacher. This interaction helps the learner make connections between their existing knowledge and the latest information to be learned. Making such connections is a critical element in learning and can often be challenging for learners with dyslexia (Reid, 2005) (For further review, see Tzivinikou, 2019). 
Proficient readers are also aware of the genre of the texts so that they can identify the differences between narrative, comparative, or argumentative texts (Bryson et al., 1991; Cox et al., 1991; McCormick et al., 1992; McCutchen, 1986; Wright \& Rosenberg, 1993). Additionally, they possess good knowledge of the written language as a symbol system (spelling, punctuation, grammar, etc.) (Applebee et al., 1990). Successful writers can also generate and organize ideas that allow them to construct texts more efficiently than poor writers (Kellogg, 1987; McCutchen et al., 1994; Tzivinikou, 2019). Afonso, Connelly, \& Barnett (2019) indicate that writing difficulties are frequently present in individuals with specific language impairment and specific learning disabilities. These students share similar characteristics with poor readers and writers.

In a higher education context, reading and writing are considered essential skills to master for university students to acquire knowledge on their discipline; therefore, students should know how to use various learning strategies effectively to enhance learning. Research has revealed substantial evidence that the effective use of reading and writing strategies can lead to academic success (Abar \& Locker, 2010; Blachowicz \& Ogle, 2008; Issa et al., 2012; Livingston, 2003; Samadi, 2004; Tzivinikou \& Fountoukidou, 2017).

Often the learning route selected by children with dyslexia is not a straightforward one; for example, problem-solving activities for students with dyslexia can include many steps to produce a result. Maybe to some, this may appear a wasteful attempt and possibly a clumsy method of getting a response. Sometimes, in subjects such as mathematics, taking too many steps to get the correct answer may lead to mistakes, and for that reason, every student must have the ability to excel in math class. One of the key points to emerge from acknowledging the various routes to learning is the learning experience that is an essential factor, particularly for the learner with dyslexia. It is crucial that dyslexic learners actively engage in the learning process, as far as possible, according to their learning preferences, resulting in less time than expected to solve a problem (Reid, 2005).

In the late 1990s, the National Reading Panel reviewed reading instruction studies to assess the different reading approaches' effectiveness. The findings showed that an effective reading program should focus on the following five instruction areas: phonemic awareness, phonics, fluency, vocabulary, and comprehension (NICHD, 2000). Comprehension becomes considerably significant to more senior students (Sweet \& Snow, 2003) as it provides the basis for further learning in secondary and tertiary education.

Some adults with dyslexia are often capable of dealing with their reading deficits by depending more on setting and top-down processing; they continue to face significant word decoding tasks and orthography issues. Moreover, while they have accomplished an average reading level, they have developed a less specific orthographic knowledge and have problems in lower-level decoding and spelling (Olofsson \& Taube, 2012). 
Phonological deficits are identified during testing the phonological awareness, pseudo-word reading, rapid naming, and verbal short-term memory. As the literature findings showed, the adults were slower than youngers on phonological processing tasks and word and pseudo-word recognition tasks. Also, they had difficulties in using decoding strategies, using more often visual cues in demanding word recognition tasks (Greenberg, Ehri, \& Perin, 2002; Miller-Shaul, 2005; Sabatini, 2002).

Kinder and Elander (2012) consider that dyslexic students are relatively disadvantaged because they use more surface approaches to learning than strategic ones. The findings indicated that students with and without dyslexia recorded a close, broad range of strategies; still, the students with dyslexia seemed to use particular visual and social strategies more consistently than did students without dyslexia.

Many other researchers share the same perspective, and they note the fact that students with learning disabilities, including dyslexia, have been found to exhibit limited strategic capacity (e.g., Bergey, Deacon, \& Parrila, 2017; Gettinger \& Seibert, 2002; Heiman \& Precel, 2003; Mortimore \& Crozier, 2006; Olofsson, Ahl, \& Taube, 2012). Other authors also reported that students with dyslexia might have particular difficulties studying the course literature, taking notes, and using selfregulated strategies or summaries, e.g., MacCullagh, Bosanquet, \& Badcock (2017), Olofsson et al. (2012). Moreover, Heiman and Precel (2003) found that students with reading difficulties preferred strategies such as oral or visual explanations more than did students without reading problems, who chose written examples.

Consistent with the above, Stampoltzis and Polychronopoulou (2009) interviewed Greek university students with dyslexia to find that some students reportedly did not use any study strategies to cope with their academic challenges. Corkett, Parrila, and Hein (2006) found that students with reading difficulties, to some degree, favoured other strategies than did students without reading difficulties. More specifically, this was related to social strategies, such as participating in classroom discussions and seeking help from other students or professionals. Several other studies also confirm this finding (e.g., Corkett, Parrila, \& Hein, 2006; Kirby, Silvestri, Allingham, Parrila, \& La Fave, 2008; Olofsson et al., 2012).

Even though some studies suggest that students with dyslexia in higher education have a limited repository of self-regulated study strategies, especially trying to avoid reading- and writing-based strategies (Heiman \& Precel, 2003; MacCullagh et al., 2017; Mortimore \& Crozier, 2006; Olofsson et al., 2012), and that some students with dyslexia have taken roles of non-strategic, passive learners (Heiman \& Precel, 2003; Stampoltzis \& Polychronopoulou, 2009), other research indicates that students with dyslexia in higher education use a wide variety of strategies (Corkett et al., 2006; Pino \& Mortari, 2014). These contradictory results may be associated with different criteria used to select participants with 
dyslexia across studies. Moreover, students with dyslexia in higher education compose a heterogeneous group as their difficulties with essential reading and spelling skills vary (Pedersen et al., 2016). It seems that poor readers with and without dyslexia tend to prefer oral, visual and social strategies.

Andreassen, Jensenn, and Bråten (2017) reported that between lecture, individual learning, and social study contexts, students with dyslexia recorded a broad range of study strategies, including not only oral, visual, and social strategies but also reading and writing strategies such as taking notes and summarizing text. Additionally, the percentage of the students with and without dyslexia who used the different strategies in the three contexts was very similar, meaning that compared to the students without dyslexia, participants with dyslexia did not seem to approach or avoid particular strategies. There were some differences within the groups regarding the frequency of using different strategies and the percentage of the time that they used them. For example, students without dyslexia used the former, text-based strategy more consistently, and students with dyslexia used the latter visual strategy more consistently. Also, among the students with and without dyslexia who recorded consulting fellow students about academic issues, this social study strategy seemed to be used more consistently by the students with dyslexia, as indicated by their percentage of use scores.

As it is evident from the above review, although the learning strategies are a well-studied subject in international literature, no similar research has been found in Greek literature. The present study aimed to discover the types of reading and writing strategies employed by undergraduate students, both typical and struggling, and identify the differences in the reading and writing strategies used between the two groups.

The study adopted the most frequently used taxonomy, developed by Oxford (1990). She proposed three direct and three indirect strategy sets. Direct strategies are specific means of language use: memory, cognitive and compensation strategies, while indirect strategies include metacognitive, affective, and social strategies, and they support the learners indirectly.

More specific, according to Oxford, memory strategies or mnemonics are powerful mental tools, grouped into four sets, creating mental linkages, applying images and sounds, reviewing and employing actions. On the other hand, there are various cognitive strategies, such as repeating, summarizing, and analyzing. Compensation strategies mainly include guessing the meaning of using linguistic and other cues. We meet the strategic trial in that strategy set to overcome speaking, reading, and writing limitations. Metacognitive strategies are beyond the cognitive, which means they are actions that provide a way for learners to coordinate their learning. They include some strategy sets, such as overviewing and linking with former knowledge, arranging, planning, organizing and setting goals and objectives, and finally self-monitoring and self-evaluating. Affective strategies refer to emotions and attitudes, and they include strategies for encouraging the learners and lowering their anxiety. Eventually, social strategies consisted of asking questions, cooperating, and empathizing with others (Oxford, 1990). 
Recently, Oxford revisited her strategy categories and developed a model with four different strategy categories: cognitive, affective, and sociocultural-interactive, as well as a master category of "meta-strategies." Meta-strategies comprise metacognitive, meta-affective and meta-sociocultural-interactive strategies (Oxford, 2016). However, our study relied on her original taxonomy (Oxford, 1990) and our previous study that began earlier than Oxford's revision.

This study aimed to investigate what strategies the participants used for reading and writing tasks and the possible significant differences in strategies usage between typical and struggling participants.

\section{Methodology}

The present study was a cross-sectional survey that compares two diverse populations at a single point in time. Two scales, (a) the Reading and (b) the Writing Strategy Scale, were constructed for data collection. The construction of these instruments was based on an initial literature review and, more specifically, on Oxford's strategies system (Oxford, 1990). The participants filled both instruments, as well as there were two open questions regarding how the participants preferred to read and write for ease.

\subsection{Participants}

The sampling was convenient, consisted of the Departments' students where the first and third authors have worked as academic staff. More specifically, two hundred thirty-three undergraduate Greek students participated in the study. Seventy-nine of them were males, and 154 were females. Their age ranged from 18 to 28 years, and the mean age was 20.10 years. Forty-six students were self-reported as struggling readers. The participants attended various graduate degree programs, such as psychology, engineering, physiotherapy, computing, business, hospitality, early and special education. Also, they reported that they use a variety of reading and writing strategies while performing academic tasks. Table 1 shows their demographic characteristics.

\subsection{Instruments}

The research instruments employed in the current study were two 5-point Likert scales, 1) the Reading Strategy Scale and 2) the Writing Strategy Scale. These instruments were developed for prior research conducted by two of the present

Table 1. Demographic characteristics of participants.

\begin{tabular}{cccc}
\hline \multirow{2}{*}{ Groups } & Typical & 205 & $88 \%$ \\
& Struggling & 28 & $12 \%$ \\
\hline \multirow{2}{*}{ Gender } & Male & 79 & $33.9 \%$ \\
& Female & 154 & $66.1 \%$ \\
\hline Age & Mean 20.10 yers & Min 18 yrs & Max 28 yrs \\
\hline
\end{tabular}


study authors, Tzivinikou and Fountoukidou (2017), and they were based on Oxford's Strategy Classification System (Oxford, 1990).

Each scale contained specific strategies grouped into six sets, 1) memory strategies ( 8 for reading and 3 for writing), 2) cognitive strategies (17 for reading and 14 for writing), 3) compensation strategies (6 for reading and 3 for writing), 4) metacognitive strategies (6 for reading and 11 for writing), 5) affective strategies (7 for both), 6) social strategies ( 3 for both) (Figure 1 ).

\section{Results}

The Cronbach alpha test conducted to measure the internal consistency of the scale and subscales. The results showed that the total scale had a very high alpha value of .933 (Table 2). Moreover, five from six subscales had high alpha values, ranging from .788 to .860 . The sixth subscale (compensation strategies) had a relatively lower alpha value of .663 (Table 2).

The initial analysis revealed that gender had a significant impact on the results. As Table 3 shows, females' and males' usage strategies were statistically significant for ten strategies, mainly regarding reading. These findings will be presented in another study (in preparation).

Moreover, the statistical analysis yielded interesting results that show that all the participants tend to use both reading and writing strategies. As for the open-ended question, "Have you ever been taught learning strategies in primary and secondary education?" the results showed that typical students identified the learning strategy instruction during their primary and secondary school studies. In contrast, struggling students reported that they had never been taught learning strategies in school.

Additional analysis revealed differences in the frequency of use of the reading and writing strategies by both groups of participants (typical and struggling

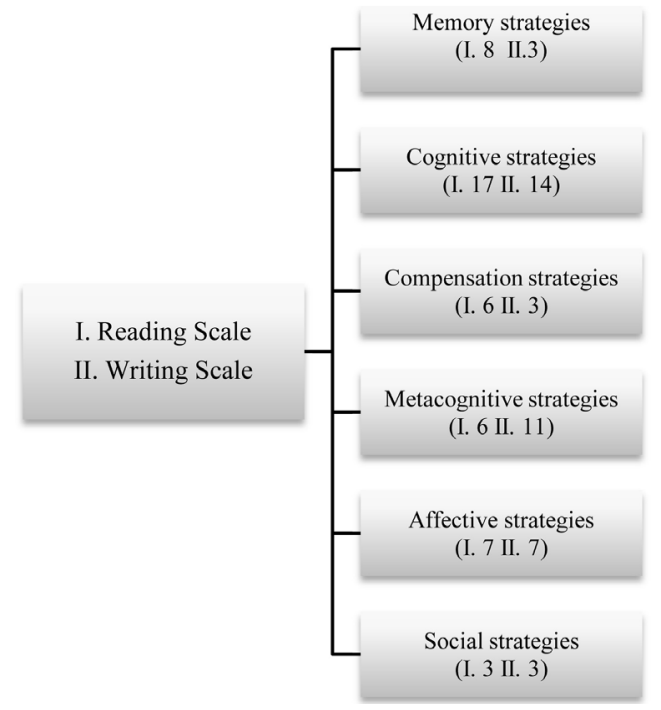

Figure 1. The groups of the reading and writing strategies contained in two scales. 
Table 2. Reliability analysis for total reading-writing scale and six subscales.

\begin{tabular}{lcc}
\hline & Cronbach's Alpha & N of Items \\
\hline \multicolumn{1}{c}{ Reading \& Writing Strategies } & .933 & 88 \\
$\quad$ Scale (Total scale) & & \\
Subscales & .705 & 11 \\
1) Memory strategies & .860 & 31 \\
2) Cognitive strategies & .663 & 9 \\
3) Compensation strategies & .785 & 17 \\
4) Metacognitive strategies & .795 & 14 \\
5) Affective strategies & .788 & 6 \\
6) Social strategies & &
\end{tabular}

Table 3. T-test (independent samples): statistically significant differences in the usage of strategies for both groups of participants (males and females).

\begin{tabular}{|c|c|c|c|c|c|c|}
\hline \multirow[t]{2}{*}{ Strategies } & \multirow[t]{2}{*}{ Gender } & \multirow[t]{2}{*}{$\mathrm{N}$} & \multirow[t]{2}{*}{ Mean } & \multirow{2}{*}{$\begin{array}{c}\text { Std. } \\
\text { Deviation }\end{array}$} & \multicolumn{2}{|c|}{$\begin{array}{l}\text { Levene's test for } \\
\text { equality of variances }\end{array}$} \\
\hline & & & & & $\mathrm{F}$ & Sig. \\
\hline \multirow{2}{*}{ Memory Reading 5} & Male & 79 & 2.5190 & 1.08440 & \multirow{2}{*}{5.556} & \multirow{2}{*}{.019} \\
\hline & Female & 154 & 2.7143 & 1.31713 & & \\
\hline \multirow{2}{*}{ Cognitive Reading 5} & Male & 79 & \multirow{2}{*}{3.70893 .5974} & .98907 & \multirow{2}{*}{9.781} & \multirow{2}{*}{.002} \\
\hline & Female & 154 & & 1.24994 & & \\
\hline \multirow{2}{*}{ Cognitive Reading 6} & Male & 79 & 3.7468 & 1.19259 & \multirow{2}{*}{5.239} & \multirow{2}{*}{.023} \\
\hline & Female & 154 & 4.2727 & .90945 & & \\
\hline \multirow{2}{*}{ Cognitive Reading 14} & Male & 79 & 2.7215 & 1.40454 & \multirow{2}{*}{3.820} & \multirow{2}{*}{.050} \\
\hline & Female & 154 & 3.7857 & 1.21518 & & \\
\hline \multirow{2}{*}{ Cognitive Reading 16} & Male & 79 & 3.3165 & 1.09245 & \multirow{2}{*}{4.871} & \multirow{2}{*}{.028} \\
\hline & Female & 154 & 3.9675 & .95943 & & \\
\hline \multirow{2}{*}{ Compensation Reading 6} & Male & 79 & 3.0127 & 1.18206 & \multirow{2}{*}{4.752} & \multirow{2}{*}{.030} \\
\hline & Female & 154 & 2.7078 & 1.26246 & & \\
\hline \multirow{2}{*}{ Metacognitive Reading 2} & Male & 79 & 3.5190 & 1.15315 & \multirow{2}{*}{9.622} & \multirow{2}{*}{.002} \\
\hline & Female & 154 & 4.0325 & 1.00599 & & \\
\hline \multirow{2}{*}{ Metacognitive Reading 3} & Male & 79 & 3.4051 & 1.38230 & \multirow{2}{*}{6.894} & \multirow{2}{*}{.009} \\
\hline & Female & 154 & 3.6429 & 1.14720 & & \\
\hline \multirow{2}{*}{ Affective Reading 7} & Male & 79 & 2.2405 & 1.14595 & \multirow{2}{*}{7.830} & \multirow{2}{*}{.006} \\
\hline & Female & 154 & 2.6558 & 1.35945 & & \\
\hline Metacoonitive Writing 9 & Male & 79 & 3.2532 & 1.37252 & 4.597 & 033 \\
\hline 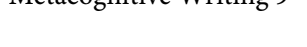 & Female & 154 & 3.3766 & 1.21040 & 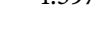 & \\
\hline$p \leq 0.05$ & & & & & & \\
\hline
\end{tabular}

readers). Still, only 13 out of the 88 strategies are statistically significant (Table 4).

As the above results seem, the typical students tend to use reading and writing strategies more often than the struggling ones. Some of the most frequently used reading strategies used by the typical students are the following:

Some memory strategies, such as: "I connect new information or words/ phrases to concepts I am familiar with", "I create mental pictures of the words I read to 
Table 4. T-test (independent samples): statistically significant differences in the usage of strategies for both groups of participants (struggling and typical).

\begin{tabular}{|c|c|c|c|c|c|c|}
\hline \multirow[t]{2}{*}{ Strategies } & \multirow[t]{2}{*}{$\begin{array}{l}\text { Struggling or } \\
\text { Typical Students }\end{array}$} & \multirow[t]{2}{*}{$\mathrm{N}$} & \multirow[t]{2}{*}{ Mean } & \multirow[t]{2}{*}{$\begin{array}{c}\text { Std. } \\
\text { Deviation }\end{array}$} & \multicolumn{2}{|c|}{$\begin{array}{l}\text { Levene's } \\
\text { Test for } \\
\text { Equality of } \\
\text { Variances }\end{array}$} \\
\hline & & & & & F & Sig. \\
\hline \multirow{2}{*}{ Cognitive Reading 3} & Struggling Students & 28 & 3.3214 & 1.36228 & 5.172 & .024 \\
\hline & Typical Students & 205 & 3.6878 & 1.06647 & & \\
\hline \multirow{2}{*}{ Cognitive Reading 4} & Struggling Students & 28 & 3.4286 & 1.52579 & 6.551 & .011 \\
\hline & Typical Students & 205 & 3.3951 & 1.21065 & & \\
\hline \multirow{2}{*}{ Cognitive Reading 6} & Struggling Students & 28 & 3.5357 & 1.42678 & 16.66 & .000 \\
\hline & Typical Students & 205 & 4.1707 & .95749 & & \\
\hline \multirow{2}{*}{ Cognitive Reading 17} & Struggling Students & 28 & 3.0000 & 1.44016 & 6.772 & .010 \\
\hline & Typical Students & 205 & 3.4293 & 1.14666 & & \\
\hline \multirow{2}{*}{ Metacognitive Reading 2} & Struggling Students & 28 & 3.5357 & 1.26146 & 4.845 & .029 \\
\hline & Typical Students & 205 & 3.9024 & 1.05265 & & \\
\hline \multirow{2}{*}{ Metacognitive Reading 3} & Struggling Students & 28 & 3.5357 & 1.52709 & 5.466 & .020 \\
\hline & Typical Students & 205 & 3.5659 & 1.19304 & & \\
\hline \multirow{2}{*}{ Affective Reading 7} & Struggling Students & 28 & 2.2500 & 1.07583 & 5.323 & .022 \\
\hline & Typical Students & 205 & 2.5512 & 1.32974 & & \\
\hline \multirow{2}{*}{ Social Reading 1} & Struggling Students & 28 & 2.7857 & 1.31535 & 4.368 & .038 \\
\hline & Typical Students & 205 & 3.4488 & 1.07720 & & \\
\hline \multirow{2}{*}{ Memory Writing 3} & Struggling Students & 28 & 2.1071 & .99403 & 5.729 & .017 \\
\hline & Typical Students & 205 & 2.2976 & 1.28500 & & \\
\hline \multirow{2}{*}{ Cognitive Writing 1} & Struggling Students & 28 & 2.7857 & 1.52406 & 7.232 & .008 \\
\hline & Typical Students & 205 & 2.8195 & 1.23336 & & \\
\hline \multirow{2}{*}{ Cognitive Writing 6} & Struggling Students & 28 & 1.9286 & .94000 & 8.214 & .005 \\
\hline & Typical Students & 205 & 2.2878 & 1.22078 & & \\
\hline \multirow{2}{*}{ Metacognitive Writing 6} & Struggling Students & 28 & 2.7500 & 1.43049 & 5.002 & .026 \\
\hline & Typical Students & 205 & 2.9561 & 1.17282 & & \\
\hline \multirow{2}{*}{ Metacognitive Writing 7} & Struggling Students & 28 & 3.2143 & 1.57191 & 5.699 & .018 \\
\hline & Typical Students & 205 & 3.3951 & 1.25830 & & \\
\hline$p \leq 0.05$ & & & & & & \\
\hline
\end{tabular}

remember them", and some cognitive strategies, such as: "I recognize and use common and fixed vocabulary (e.g. as regards, etc.)", "I read the title of the text to get the general idea of the text", "I read the text carefully to find the information I need", "I use a dictionary to search for the meaning of unknown words" and "I use prior knowledge to understand what I read".

On the other hand, some of the most frequently used reading strategies for struggling students are some memory strategies, such as: "I create mental pictures of the words I read to remember them", and some cognitive strategies, 
such as: "I can recognize and use frequent/common vocabulary and fixed expressions", "I check whether my guesses/ inferences about the text are correct", "I scanned the text to get the main ideal $s$ " and "I read the text carefully to find the information I need".

To continue, some of the most common writing strategies used by typical students are a large number of cognitive strategies, such as: "After writing something, I try to detect grammar, syntax and spelling errors to make the necessary corrections", "I recognize and use common and fixed vocabulary (e.g. as regards, etc.)", "Before writing an essay I brainstorm, make a draft". On the other hand, some metacognitive strategies, such as: "I think whether the content of the text is suitable for my purpose", "Before writing a text I think about the genre and conventions", "Before writing a text I think about the appropriate vocabulary $1 \mathrm{~m}$ required to use", "Before writing a text I think about the steps that I should follow".

The writing strategies preferred by the struggling students, on the other hand, are some cognitive strategies, such as: "I use acronyms to remember the terminology", "When I manage to understandl write a difficult text, I reward myself (e.g. go for a walk with my friends, buy a bar of chocolate, etc.)", and some metacognitive strategies, like: "When I write I like cooperating with my co-students and exchange ideas on what we write", "When I write I translate from one language to the other to include information I need for my assignment".

\section{Discussion}

It is widely accepted that learning strategies facilitate learning acquisition. Oxford's Classification System (Oxford, 1990) about language strategies is well documented in the literature, mainly for typical persons. The current study had adopted and adjusted Oxford's classification system to be implemented for different sampling than Oxford's one. The overall findings showed some substantial differences in reading and writing strategies using by the typical and struggling readers.

Initially, the findings showed that gender had a significant impact on choosing the learning strategies selected by males and females. It was an interesting finding, and it will be presented in more detail in another study in preparation.

As the research question on the types of literacy learning strategies by both groups of participants, it was found that the typical students used literacy strategies more often than struggling students. The above findings are consistent with the first and second authors' previous study (Tzivinikou \& Fountoukidou, 2017). Besides, they adhere to the results of the literature. For example, Heiman and Precel (2003) found that students with reading difficulties prefer strategies such as oral or visual explanations more than did students without reading problems, who chose written examples. Also, students with learning disabilities may face particular challenges with strategies including reading and writing, such as studying the course literature, taking notes, producing and using summaries (Mac- 
Cullagh et al., 2017; Mortimore \& Crozier, 2006; Olofsson et al., 2012).

Furthermore, findings are consistent with Afonso, Connelly, \& Barnett (2019), who indicated that writing difficulties are frequently present in struggling individuals. Also, Corkett, Parrila, and Hein (2006) found that students with reading difficulties to some degree favoured different strategies than did students without reading difficulties. More specifically, this was related to social strategies such as participating in classroom discussions and seeking help from other students or professionals.

So, although struggling students use fewer reading and writing strategies, they show a preference for cognitive and metacognitive strategies. These findings were consistent with the results of Andreassen, Jensenn, and Bråten (2017). They suggested that struggling students recorded a broad range of study strategies across various learning contexts, including oral, visual, and social strategies and reading and writing strategies such as taking notes and summarizing text.

\section{Conclusion}

Oxford's Classification System (Oxford, 1990) about language strategies is welldocumented in the literature, mainly for typical students. The present study focusing on the struggling readers adjusted this classification system to identify the differences in the reading and writing strategies used by typical and struggling readers.

Overall, the current study's research findings suggest that typical students use reading and writing strategies more often than struggling students. These findings are consistent with similar research (e.g., Corkett, Parrila, \& 2006; Heiman \& Precel, 2003; MacCullagh, Bosanquet, \& Badcock, 2017; Mortimore \& Crozier, 2006; Olofsson et al., 2012; Tzivinikou \& Fountoukidou, 2017). It is essential to mention that this study underlines the fact that although struggling students use fewer reading and writing strategies, they also show a preference towards cognitive and metacognitive strategies, following the results of previous research (Andreassen, Jensenn, \& Bråten, 2017; Tzivinikou \& Fountoukidou, 2017).

A possible limitation of the study was the sampling technique, the convenient sampling. As it is well-known, convenience sampling has some advantages but much more disadvantages. For example, this technique is highly vulnerable to selection bias and influences beyond the researcher's control, and it might have a high level of sampling error.

This study's findings advocate in favour of the reading and writing strategies instruction to promote academic success and be considered a reference for additional research in teaching the above skills. A combination of integrated strategy instruction instead of specific cognitive, metacognitive, affective, compensation, social or memory strategies would be more advantageous for students (Oxford, 2002). It could bring positive learning outcomes reinforcing students' learning ability and learning efficiency. Teachers should also take the responsibility to teach their students how to use learning strategies consciously to respond to the chal- 
lenges that a specific task may impose on the student and address it successfully by selecting appropriate learning strategies.

\section{Conflicts of Interest}

The authors declare no conflicts of interest regarding the publication of this paper.

\section{References}

Abar, B., \& Locker, E. (2010). Self-Regulated Learning and Self-Directed Study in a Pre-College Sample. Learning and Individual Differences, 20, 25-29. https://doi.org/10.1016/j.lindif.2009.09.002

Afonso, O., Connelly, V., \& Barnett, A. L. (2019). Struggling with Writing: An Examination of Writing Difficulties in Specific Language Impairment, Developmental Dyslexia and Developmental Coordination Disorder. In Spelling and Writing Words (pp. 112127). Leiden: Brill. https://doi.org/10.1163/9789004394988 007

Anderson, N. (2003) Scrolling, Clicking, and Reading English: Online Reading Strategies in a Second/Foreign Language. The Reading Matrix, 3, 1-33.

Andreassen, R., Jensen, M. S., \& Bråten, I. (2017). Investigating Self-Regulated Study Strategies among Postsecondary Students with and without Dyslexia: A Diary Method Study. Reading and Writing, 30, 1891-1916. https://doi.org/10.1007/s11145-017-9758-9

Antoniou, A.S., Geralexis, I., \& Charitaki, G. (2017). Special Educators' Teaching Self-Efficacy Determination: A Quantitative Approach. Psychology, 8, 1642-1656. https://doi.org/10.4236/psych.2017.811108

Applebee, A. N., Langer, J. A., Jenkins, L. B., Mullis, I., \& Foertsch, M. A. (1990). Learning to Write in our Nation's Schools. Washington, DC: U.S. Department of Education: Office of Educational Research and Improvement.

Bergey, B. W., Deacon, S. H., \& Parrila, R. K. (2017). Metacognitive Reading and Study Strategies and Academic Achievement of University Students with and without a History of Reading Difficulties. Journal of Learning Disabilities, 50, 81-94.

https://doi.org/10.1177/0022219415597020

Blachowicz, C., \& Ogle, D. (2008). Reading Comprehension: Strategies for Independent Learners (2nd ed.). New York: The Guilford Press.

Block, E. (1992). See How They Read: Comprehension Monitoring of L1 and L2 Readers. TESOL Quarterly, 26, 319-343. https://doi.org/10.2307/3587008

Brown, A. L., Bransford, J. D., Ferrara, R. A., \& Campione, J. C. (1983). Learning, Remembering, and Understanding. In P. H. Mussen (Ed.), Handbook of Child Psychology: Vol. 3. Cognitive Development (pp. 77-166). New York: Wiley.

Bryson, M., Bereiter, C., Scardamalia, M., \& Joram, E. (1991). Going Beyond the Problem as Given: Problem-Solving in Expert and Novice Writers. In R. J. Sternberg, \& P. A. French (Eds.), Complex Problem Solving: Principles and Mechanisms (pp. 61-84). Hillsdale, NJ: Erlbaum.

Corkett, J. K., Parrila, R., \& Hein, S. F. (2006). Learning and Study Strategies of University Students Who Report a Significant History of Reading Difficulties. Developmental Disabilities Bulletin, 34, 57-79.

Cox, B. E., Shanahan, T., \& Sulzby, E. (1991). Good and Poor Elementary Reader's Use of Cohesion in Writing. Reading Research Quarterly, 25, 47-65.

https://doi.org/10.2307/747987 
Cunningham, A. E., \& Stanovich, K. E. (1998). What Reading Does for the Mind? American Educator, 22, 8-15.

Gettinger, M., \& Seibert, J. K. (2002). Contributions of Study Skills to Academic Competence. School Psychology Review, 31, 350-365. https://doi.org/10.1080/02796015.2002.12086160

Graham, S., \& Harris, K. R. (1992). Self-Regulated Strategy Development: Programmatic Research in Writing. In B. Y. L. Wong (Ed.), Contemporary Intervention Research in Learning Disabilities: An International Perspective (pp. 47-64). New York: SpringerVerlag. https://doi.org/10.1007/978-1-4612-2786-1 3

Graham, S., \& Perry, M. (1993). Indexing Transitional Knowledge. Developmental Psychology, 29, 779-788. https://doi.org/10.1037/0012-1649.29.4.779

Greenberg, D., Ehri, L. C., \& Perin, D. (2002). Do Adult Literacy Students Make the Same Word-Reading and Spelling Errors as Children Matched for Word-Reading Age? Scientific Studies of Reading, 6, 221-243. https://doi.org/10.1207/S1532799XSSR0603 2

Heiman, T., \& Precel, K. (2003). Students with Learning Disabilities in Higher Education: Academic Strategies Profile. Journal of Learning Disabilities, 36, 248-258.

https://doi.org/10.1177/002221940303600304

Issa, A. O., Aliyu, M. B., Akangbe, R. B., \& Adedeji, A. F. (2012) Reading Interest and Habits of the Federal Polytechnic Students. International Journal of Learning and Development, 2, 470-486. https://doi.org/10.5296/ijld.v2i1.1470

Kellogg, R. T. (1987). Effects of Topic Knowledge on the Allocation of Processing Time and Cognitive Effort to Writing Processes. Memory and Cognition, 15, 256-266.

https://doi.org/10.3758/BF03197724

Kinder, J., \& Elander, J. (2012). Dyslexia, Authorial Identity, and Approaches to Learning and Writing: A Mixed-Methods Study. British Journal of Educational Psychology, 82, 289-307. https://doi.org/10.1111/j.2044-8279.2011.02026.x

Kirby, J. R. (1988) Style, Strategy, and Skill in Reading. In R. R. Schmeck (Ed.), Learning Strategies and Learning Styles (pp. 229-274). New York: Plenum Press. https://doi.org/10.1007/978-1-4899-2118-5 9

Kirby, J. R., Silvestri, R., Allingham, B. H., Parrila, R., \& La Fave, C. B. (2008). Learning Strategies and Study Approaches of Postsecondary Students with Dyslexia. Journal of Learning Disabilities, 41, 85-96. https://doi.org/10.1177/0022219407311040

Livingston, J. A. (2003). Metacognition: An Overview. Psychology, 13, 259-266.

MacCullagh, L., Bosanquet, A., \& Badcock, N. A. (2017). University Students with Dyslexia: A Qualitative Exploratory Study of Learning Practices, Challenges and Strategies. Dyslexia, 23, 3-23. https://doi.org/10.1002/dys.1544

Mayer, R. E. (1988). Learning Strategies: An Overview. In C. E. Weinstein, E. T. Goetz, \& P. A. Alexander (Eds.), Learning and Study Strategies: Issues in Assessment, Instruction, and Evaluation (pp. 11-22). New York: Academic Press. https://doi.org/10.1016/B978-0-12-742460-6.50008-6

McCormick, C. B., Busching, B. A., \& Potter, E. F. (1992). Children's Knowledge about Writing: The Development and Use of Narrative Criteria. In M. Pressley, K. R. Harris, \& J. T. Gutherie (Eds.), Promoting Academic Competence and Literacy in School (pp. 331-336). San Diego, CA: Academic Press.

McCutchen, D. (1986). Domain Knowledge and Linguistic Knowledge in the Development of Writing Ability. Journal of Memory and Language, 25, 431-444. https://doi.org/10.1016/0749-596X(86)90036-7

McCutchen, D., Covill, A., Hoyne, S. H., \& Mildes, K. (1994). Individual Differences in 
writing: Implications of Translating Fluency. Journal of Educational Psychology, 86, 256-266. https://doi.org/10.1037/0022-0663.86.2.256

Meltzer, L. J., Roditi, B. N., Steinberg, J. L., Rafter Biddle, K., Taber, S. E., Boyle Caron, K., \& Kniffin, L. (2006). Strategies for Success: Classroom Teaching Techniques for Students with Learning Differences. Austin, TE: PRO-ED, Inc.

Miller-Shaul, S. (2005). The Characteristics of Young and Adult Dyslexics Readers on Reading and Reading-Related Cognitive Tasks as Compared to Normal Readers. Dyslexia, 11, 132-151. https://doi.org/10.1002/dys.290

Mitchell, D., \& Sutherland, D. (2020). What Really Works in Special and Inclusive Education: Using Evidence-Based Teaching Strategies? London: Routledge.

https://doi.org/10.4324/9780429401923

Mokhtari, K., \& Reichard, C. (2004). Investigating the Strategic Reading Processes of First and Second Language Readers in Two Different Cultural Contexts. System, 32, 379-394. https://doi.org/10.1016/j.system.2004.04.005

Mokhtari, K., \& Sheorey, R. (2002). Measuring ESL Students' Awareness of Reading Strategies. Journal of Developmental Education, 25, 2-11.

Mortimore, T., \& Crozier, W. R. (2006). Dyslexia and Difficulties with Study Skills in Higher Education. Studies in Higher Education, 31, 235-251.

https://doi.org/10.1080/03075070600572173

National Institute of Child Health and Human Development (NICHD) (2000). Report of the National Reading Panel. Teaching Children to Read: An Evidence-Based Assessment of the Scientific Research Literature on Reading and Its Implications for Reading Instruction (NIH Publication No. 00-4769). Washington, DC: U.S. Government Printing Office.

Nisbet, J. D., \& Shucksmith, J. (2017). Learning Strategies. Routledge Education Books. Boston, MA: Routledge \& K. Paul. https://doi.org/10.4324/9781315188652

Olofsson, Å., Ahl, A., \& Taube, K. (2012). Learning and Study Strategies in University Students with Dyslexia: Implications for Teaching. Procedia-Social and Behavioral Sciences, 47, 1184-1193. https://doi.org/10.1016/j.sbspro.2012.06.798

Oxford, R. (2002). Chapter 11. Language Learning Strategies in a Nutshell: Update and ESL Suggestions. In J. Richards, \& W. Renandya (Eds.), Methodology in Language Teaching: An Anthology of Current Practice (Cambridge Professional Learning) (pp. 124-132). Cambridge: Cambridge University Press. https://doi.org/10.1017/CBO9780511667190.018

Oxford, R. L. (1990). Language Learning Strategies: What Every Teacher Should Know. New York: Newbury House.

Oxford, R. L. (2016). Teaching and Researching Language Learning Strategies: Self-Regulation in Context. New York: Routledge. https://doi.org/10.4324/9781315719146

Palincsar, A. S., \& Brown, A. L. (1984). Reciprocal Teaching of Comprehension-Fostering and Comprehension-Monitoring Activities. Cognition and Instruction, 1, 117-175. https://doi.org/10.1207/s1532690xci0102_1

Paris, S., Lipson, M., \& Wixson, K. (1983). Becoming a Strategic Reader. Contemporary Educational Psychology, 8, 293-316. https://doi.org/10.1016/0361-476X(83)90018-8

Pedersen, H. F., Fusaroli, R., Lauridsen, L. L., \& Parrila, R. (2016). Reading Processes of University Students with Dyslexia-An Examination of the Relationship between Oral Reading and Reading Comprehension. Dyslexia, 22, 305-321.

https://doi.org/10.1002/dys.1542

Pino, M., \& Mortari, L. (2014). The Inclusion of Students with Dyslexia in Higher Educa- 
tion: A Systematic Review Using Narrative Synthesis. Dyslexia, 20, 346-369.

https://doi.org/10.1002/dys.1484

Pressley, M. \& Afflerbach, P. (1995). Verbal Protocols of Reading: The Nature of Constructively Responsive Reading. Hillsdale, NJ: Erlbaum.

Reid, G. (2005). Dyslexia and Inclusion: Classroom Approaches for Assessment. Teaching and Learning. London: David Fulton Publisher.

Rigney, J. W. (1978). Learning Strategies: A Theoretical Perspective. In H. F. O’Neil (Ed.), Learning Strategies (pp. 165-205). New York: Academic Press.

Sabatini, J. P. (2002). Efficiency in Word Reading of Adults: Ability Group Comparisons. Scientific Studies of Reading, 6, 267-298. https://doi.org/10.1207/S1532799XSSR0603 4

Samadi, M. (2004). Role of Self-Regulation Strategies in Mathematic Problem Solving of Students. Quarterly of Educational Innovations, 7, 73-97.

Stampoltzis, A., \& Polychronopoulou, S. (2009). Greek University Students with Dyslexia: An Interview Study. European Journal of Special Needs Education, 24, 307-321. https://doi.org/10.1080/08856250903020195

Sweet, A. P., \& Snow, C. E. (2003). Rethinking Reading Comprehension. New York: Guilford Press.

Tzivinikou, S. (2019). Assess, Plan and Teach. Effective Interventions on Reading and Writing for Learning Disabled Students. Volos: Readnet Publications. (In Greek)

Tzivinikou, S., \& Fountoukidou, A. (2017). Reading and Writing Strategies Employed by Undergraduate and Postgraduate Students. The 3rd Pan-Hellenic Conference with International Participation, Heraklion, 5-7 May 2017.

Wright, R.E., \& Rosenberg, S. (1993) Knowledge of Text Coherence and Expository Writing: A Developmental Study. Journal of Educational Psychology, 85, 152-158.

https://doi.org/10.1037/0022-0663.85.1.152 